Section Editor

John J. Millichap, MD

Mystery Case:

\title{
Dural melanocytoma with leptomeningeal melanocytosis
}

Mark Schembri, MD, FRCR

Hong Kuan Kok, MB, FFRRCSI, FRCR

Paul Brennan, MB, FFRRCSI, FRCR

Alan O'Hare, MB, FFRRCSI

John Thornton, MB, FFRRCSI

Seamus Looby, MB, FFRRCSI

Hamed Asadi, MD, FRANZCR

Correspondence to

Dr. Asadi:

asadi.hamed@gmail.com

\section{Figure 1 Contrast-enhanced T1 of the cervical spine and brain}

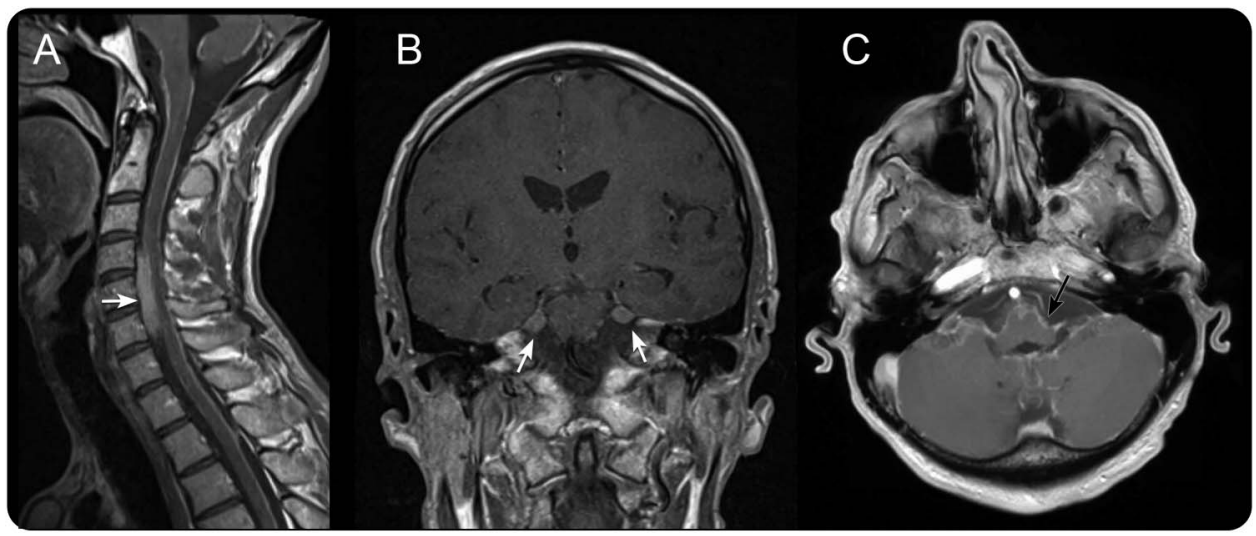

(A) Contrast T1 demonstrates the cervical lesion with (B) bilateral involvement of trigeminal nerves extending into Meckel caves and $(\mathrm{C})$ enhancement of the leptomeninges.

A 53-year-old man presented with a 1-month history of upper back pain. CSF examination was normal and imaging showed a midcervical avidly enhancing mass, with diffuse leptomeningeal abnormality (figure 1), suspicious for dural melanocytosis.

Meningeal melanocytomas are rare tumors derived from leptomeningeal melanocytes, with the aggressive subtype considered a rare variant of malignant melanoma, carrying a poor prognosis. Spinal involvement is classically seen as an intradural, extramedullary lesion in the upper cervical spine, consistent with the cellular distribution.

Imaging relies on T1-weighted shortening owing to the paramagnetic effects of melanin on MRI, and no evidence of blood products on T2* imaging (figure 2). ${ }^{2}$

Surgical excision confirmed intermediate-grade dural melanocytoma.

\section{AUTHOR CONTRIBUTIONS}

Mark Schembri: acquisition of data and drafting of manuscript. Hong Kuan Kok: acquisition of data and review of manuscript. Paul Brennan: interpretation of data. Alan O'Hare: interpretation of data. John Thornton: interpretation of data. Seamus Looby: interpretation of data. Hamed Asadi: interpretation of data and review and revision of manuscript.

\section{STUDY FUNDING}

No targeted funding reported.

\section{DISCLOSURE}

The authors report no disclosures relevant to the manuscript. Go to Neurology.org for full disclosures.

\section{REFERENCES}

1. Shanthi V, Ramakrishna BA, Bheemaraju VV, Rao NM, Athota VRM. Spinal meningeal melanocytoma: a rare meningeal tumor. Ann Indian Acad Neurol 2010;13:308-310.

2. Smith AB, Rushing EJ, Smirniotopoulos JG. Pigmented lesions of the central nervous system: radiologic-pathologic correlation. Radiographics 2009;29:1503-1524.

\section{MYSTERY CASE RESPONSES}

The Mystery Case series was initiated by the Neurology ${ }^{\circledR}$ Resident \& Fellow Section to develop the clinical reasoning skills of trainees. Residency programs, medical student preceptors, and individuals were invited to use this Mystery Case as an educational tool. Responses were solicited through a group e-mail sent to the American Academy of Neurology Consortium of Neurology Residents and Fellows and through social media. We received 314 responses. The majority of respondents $(65 \%)$ had practiced for 1-4 years; $45 \%$ were residents/ fellows while $38 \%$ were faculty/board-certified physicians, $10 \%$ were medical students, and $7 \%$ were advanced practice providers. A large majority,

From the Neuroradiology and Neurointerventional Service (M.S., H.K.K., P.B., A.O., J.T., S.L., H.A.), Department of Radiology, Beaumont Hospital, Dublin, Ireland; and School of Medicine (H.A.), Faculty of Health, Deakin University, Waurn Ponds, Australia. 
Figure 2 Sagittal precontrast T1 and gradient-echo sequence

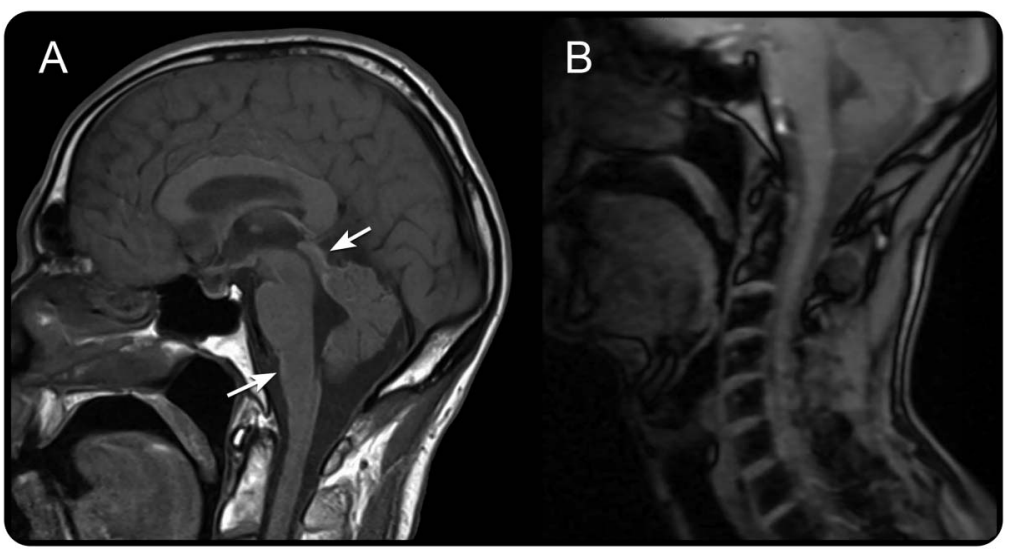

(A) Precontrast T1 demonstrates high signal in the leptomeninges. (B) There is no corresponding blooming artefact on gradient-echo sequence indicative of blood products.

79\%, resided outside the United States. A wide range of practice settings was represented. ${ }^{1}$

Proving to be a difficult case, only $10 \%$ of participants correctly identified the most likely diagnosis, meningeal melanocytoma. The most common diagnostic response was epidural abscess (25\%), followed by leptomeningeal carcinomatosis $(16 \%)$ and sarcoidosis (13\%). An epidural abscess usually appears as an extradural, extramedullary lesion, while the cervical MRI in this case showed a contrastenhancing intradural, extramedullary lesion, imaging features identified by $45 \%$ of responders. In addition, there are bilateral trigeminal nerve lesions extending into Meckel caves (4.7\%) and diffuse leptomeningeal enhancement (26.7\%) on T1 precontrast and postcontrast images. Together, these imaging findings could not be explained by leptomeningeal carcinomatosis alone, and while neurosarcoidosis does classically involve the leptomeninges, the noncaseating granulomas also tend to directly invade the brainstem and spinal cord, a situation not depicted here. Subtler imaging clues include T1-weighted shortening $(13 \%)$ related to the paramagnetic effects of melanin on MRI as well no gradient-echo blooming $(8 \%)$, making hematoma or vascular malformation less likely. Imaging alone cannot reliably distinguish meningeal melanocytoma from other extra-axial neoplasms such as meningiomas, schwannomas, and malignant melanoma, which can occur in similar locations. Definitive diagnosis ultimately hinges on pathologic and histologic features of tissue as well as careful investigation for a primary lesion outside of the CNS. Rare tumors, meningeal melanocytomas are derived from leptomeningeal melanocytes and are typically slow-growing.

This case highlights the importance of carefully integrating discrete imaging features to arrive at a narrowed differential. Doing so should shorten the time needed to obtain the final diagnosis.

Steve O'Donnell, MD

Neurology Resident, Department of Neurology, University of Utah, Salt Lake City

\section{REFERENCE}

1. Smith AB, Rushing EJ, Smirniotopoulos JG. Pigmented lesions of the central nervous system: radiologic-pathologic correlation. Radiographics 2009;29:1503-1524. 


\section{Neurology}

\section{Mystery Case: Dural melanocytoma with leptomeningeal melanocytosis \\ Mark Schembri, Hong Kuan Kok, Paul Brennan, et al. \\ Neurology 2017;88; 70 -e71 \\ DOI 10.1212/WNL.0000000000003654}

This information is current as of February 27, 2017

Updated Information \& Services

References

Subspecialty Collections

Permissions \& Licensing

Reprints including high resolution figures, can be found at: http://n.neurology.org/content/88/9/e70.full

This article cites 3 articles, 0 of which you can access for free at: http://n.neurology.org/content/88/9/e70.full\#ref-list-1

This article, along with others on similar topics, appears in the following collection(s):

\section{MRI}

http://n.neurology.org/cgi/collection/mri

Spinal cord tumor

http://n.neurology.org/cgi/collection/spinal_cord_tumor

Information about reproducing this article in parts (figures,tables) or in its entirety can be found online at:

http://www.neurology.org/about/about_the_journal\#permissions

Information about ordering reprints can be found online:

http://n.neurology.org/subscribers/advertise

Neurology ${ }^{\circledR}$ is the official journal of the American Academy of Neurology. Published continuously since 1951, it is now a weekly with 48 issues per year. Copyright (O 2017 American Academy of Neurology. All rights reserved. Print ISSN: 0028-3878. Online ISSN: 1526-632X.

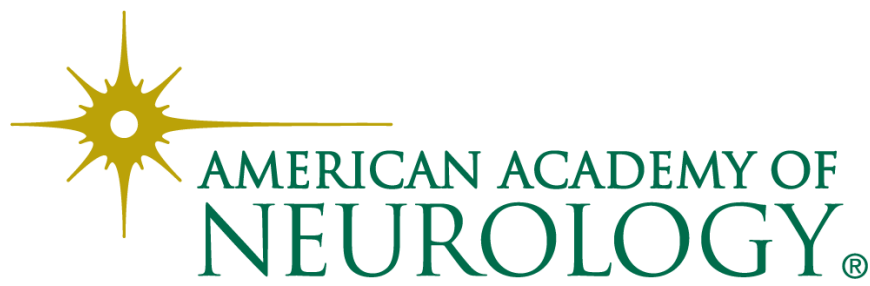

